\title{
Is cellulase production by solid-state fermentation economically attractive for the second generation ethanol production?
}

\author{
Fabrício Bruno Mendes*, Daniel Ibraim Pires Atala, João Cláudio Thoméo \\ Departamento de Engenharia e Tecnologia de Alimentos - UNESP, São Jose do Rio Preto, São Paulo, Brazil
}

\section{A R T I C L E I N F O}

\section{Article history:}

Received 21 February 2017

Received in revised form

11 July 2017

Accepted 13 July 2017

Available online 14 July 2017

\section{Keywords:}

Enzyme

Cellulase

Solid-state fermentation

Economic analysis

Second generation ethanol

\begin{abstract}
A B S T R A C T
The cost of enzymes for the enzymatic route of the second generation ethanol production is a crucial bottleneck to turn this process into a reality. Solid-state fermentation (SSF) is an environmentally friendly process of enzyme synthesis, although little is known about the costs associated to it. Therefore, this work analyzed economical scenarios of cellulase production by SSF in a pilot plant integrated to both a first and a second generation ethanol processes. The chosen substrate for the enzyme production was composed by sugarcane bagasse and wheat bran, cultivated by the thermophilic fungus Myceliophthora thermophila I-1D3b at $45{ }^{\circ} \mathrm{C}$ during $96 \mathrm{~h}$. The estimation of the most important economic indicators showed that the SSF process is economically attractive, due to its easy integration to the main process, and its revenue is up to four fold greater than electricity cogeneration. Economic indicators, such as the internal rate of return (IRR) and payback, were higher than those usually accepted by Brazilian investor in the sucro-energetic sector. Nevertheless, return on investment (ROI) was under than that recommended by the literature. The sensitivity analysis showed strong influence of the enzyme activity on the economic indicators, being the most important parameter for the project profitability.
\end{abstract}

(c) 2017 Elsevier Ltd. All rights reserved.

\section{Introduction}

Bio-based processes are receiving a massive attention from the scientific community, since they are sustainable and ecologically friendly alternatives to face the finite stocks of fossil resources and the greenhouse effects. Examples of using agro-industrial residues and municipal wastes in sustainable processes include the production of biofuels, bioenergy, biogas, and biomaterials.

In Brazil, the conventional production of ethanol from sugarcane juice, also known as first generation ethanol (E1G), is an industrial reality since $88.4 \%$ of all light vehicles produced in the country in 2015 were flexible [1], meaning that they could be powered by gasoline, ethanol, or mixtures between them. Sugarcane bagasse (SCB) and sugarcane straw (SCSt) are leftovers of the E1G production that corresponds to $25 \%$ and $16 \%$ of the whole cane, respectively (142 million tons and 94 million tons in the season 2014/ 2015 , respectively) [2]. Nowadays, SCB is burned in power plants to cogenerate electrical energy and heat, although also generating greenhouse gases and suspended particulates, while SCSt is left in

\footnotetext{
* Corresponding author.

E-mail address: fabrunom@gmail.com (F.B. Mendes).
}

the field. Therefore, the production of the second-generation ethanol (E2G) from bagasse and straw is an example of sustainable alternative, for which the enzymatic route is the most environmentally friendly.

The use of sugarcane bagasse to produce ethanol does not compete with human food supplies and does not impose additional impact to the environment and its biodiversity, since sugarcane is already planted in Brazil to produce ethanol and sugar in a proportion of 50\% for each product. According to Brazilian Agricultural Supply - CONAB, in 2015 , the area dedicated to sugarcane production remained stable in relation to previous years $(-0.1 \%$ mil hectare) and the productivity increased $3.9 \%$ in $\mathrm{kg}$ sugarcane per hectare [3]. Therefore, the production of E2G would represent an increase for ethanol production without the increase of the planted area. Additionally, lignocellulosic materials have little value for human nutrition [4].

The enzymatic route to produce E2G is the lesser aggressive to the environment, since it generates little chemical wastes to be treated. However, the high cost of the commercial enzymes developed for such purpose by the mainstream commercial companies is a major bottleneck to turn the E2G into a reality. To overcome this drawback, sugarcane mills can locally produce enzymes, and solid-state fermentation (SSF) is an important 
alternative for such purpose, since the substrates for the fungal growth are usually solid wastes from the agro-industrial sector. Several works have been published in literature presenting new microorganisms and improving the fermentation conditions to produce fibrolytic enzymes capable to hydrolyze biomass efficiently (e.g., see the reviews of [5,6]). Particularly, some studies showed the viability of producing cellulases and hemicellulases of industrial interest by SSF in glass flask and in bench bioreactor scale [7-12]. SSF is also advantageous over submerged fermentation ( $\mathrm{SbF}$ ) when considering the costs to avoid microbial contamination of the production plant, due to the lower water activity of the SSF process; therefore, the enzyme production plant (EPP) could be built besides the E1G and E2G processes, usually not a clean place, resulting in an integration based on the solid wastes [13].

In this context, it should be considered the strategy of building the EPP integrated to the E1G and E2G production plants. Some investments in new equipment would be required, though some process utilities and employees could be shared by the processes. Therefore, this work aimed to evaluate the economic feasibility of a plant to produce enzymes by SSF adjoined to productions plants of E1G and E2G, having sugarcane bagasse and wheat bran as substrates and a thermophilic fungus as a microbial agent. In this approach, it is supposed that the enzymes will be locally consumed by the E2G production plant, even though the later process is not the object of this study. Different scenarios of availability of sugarcane bagasse and wheat bran were analyzed and the minimal economic condition was found. An economic comparison was made between the gains with the production of the enzymes and the profits obtained by selling electrical energy to the spot market, and the enzyme production by SSF showed to be an attractive alternative.

\subsection{Enzymatic hydrolysis of biomass and enzyme market}

Enzymatic hydrolysis of vegetal biomass is an advantageous alternative when compared with the chemical hydrolysis, since it results in lower costs of equipment and higher yields of sugars of low molecular weight [14]. Besides, the chemical hydrolysis generates inhibitors of the subsequent ethanolic fermentation, such as furfural and hydroxymethylfurfural. On the other hand, enzymes represent the third highest cost of the E2G process, following capital and feedstock $[15,16]$.

Biomass is a complex structure mainly composed by cellulose, hemicellulose and lignin and in its natural state biomass is recalcitrant to the enzyme action. Therefore, physical or chemical pretreatments are mandatory to expose cellulose and hemicellulose to the attack of the enzymes. The cellulase complex comprises endoglucanases, cellobiohydrolases and $\beta$-glucosidases, while the hemicellulase complex include endo- and exo-xylanases, galactanases, xyloglucanases and mannanases. The enzymes must act in synergy to avoid self-inhibition by end-products, resulting in high yields of hexoses and pentoses. The efficiency of a specific enzymatic preparation to hydrolyze the biomass is difficult to assess, since several factors are associated to the biomass depolymerization, such as type of pretreatment, enzymes present in the preparation and their activities, environmental conditions (e.g. temperature, $\mathrm{pH}$, soluble and insoluble solid concentrations), and reaction time [17-19]. Some intrinsic properties of the enzymes are also relevant when considering the performance of conversion, such as stability, specificity, spatial conformation and synergism among the different enzymes [20]. Most of these factors are interwoven and comparing commercial and laboratory preparations is a difficult task. Nevertheless, some researchers claimed that cellulases produced by SSF present activity similar to the enzymes produced by SbF, including the ones present in the commercial preparations [20-22].

The world market of industrial enzymes is highly concentrated, since $74 \%$ of it is shared by Novozymes (47\%), DuPont (21\%) and DSM (6\%) [23]; hence, developing new technologies to produce enzymes and enhance their catalytic capability is strategic. The market value of cellulases is not standardized, since a variety of indexes is used to indicate the enzyme activity, as can be seen in Table 1. According to Klein-Marcuschamer et al. [24], such mismatch among those commercial indexes represents a drawback to a robust technical-economic analysis of the bioethanol process production.

\subsection{On-site enzyme production by solid-state fermentation}

In Brazilian sucro-energetic industries, some available utilities might be shared by the E1G and the E2G process, such as steam, electrical energy, water, feedstock and some technical personal. Considering an on-site SSF enzyme production plant, the same utilities could be shared, optimizing resources and reducing costs. Fig. 1 presents the integration of the E1G, E2G and EPP. Such integration is interesting, since the sugarcane is cropped nearby the E1G unity, reducing transportation costs. Besides, the cane straw could be fetched to the E1G unity either to be burned to generate electrical energy and heat or to be used as a feedstock by the E2G plant. Hence, a surplus of sugarcane bagasse is expected to be used as a feedstock in the SSF plant.

One might consider building the EPP in a midpoint among sugar mills, in order to avoid having one EPP for each E2G process, allowing that a pool of mills to share the produced enzymes. Nevertheless, besides the costs of the process utilities and the bagasse transportation that a stand alone EPP would require, the

Table 1

Cost of commercial cellulases according to the literature.

\begin{tabular}{ll}
\hline Reference & Value (US\$) \\
\hline Greer $(2005)^{\mathrm{a}}$ & 0,10 to $0,30 / \mathrm{L}$ ethanol produced \\
Kazi et al. $(2010)^{\mathrm{b}}$ & 0,89 to $1,25 / \mathrm{L}$ ethanol produced \\
Klein-Marcuschamer et al. $(2012)^{\mathrm{b}}$ & $0,09 / \mathrm{L}$ ethanol produced \\
CTBE $(2011)^{\mathrm{b}}$ & $0,11 / \mathrm{L}$ ethanol produced \\
NCBE $(2015)^{\mathrm{c}}$ & $0,22 / \mathrm{mL}$ \\
\hline Notes: & \\
a Based on information from Genencor (currently DuPont) and Novozymes. \\
b Non specified commercial supplier. \\
c Retail value of the commercial product Celluclast provided by NCBE (2015).
\end{tabular}

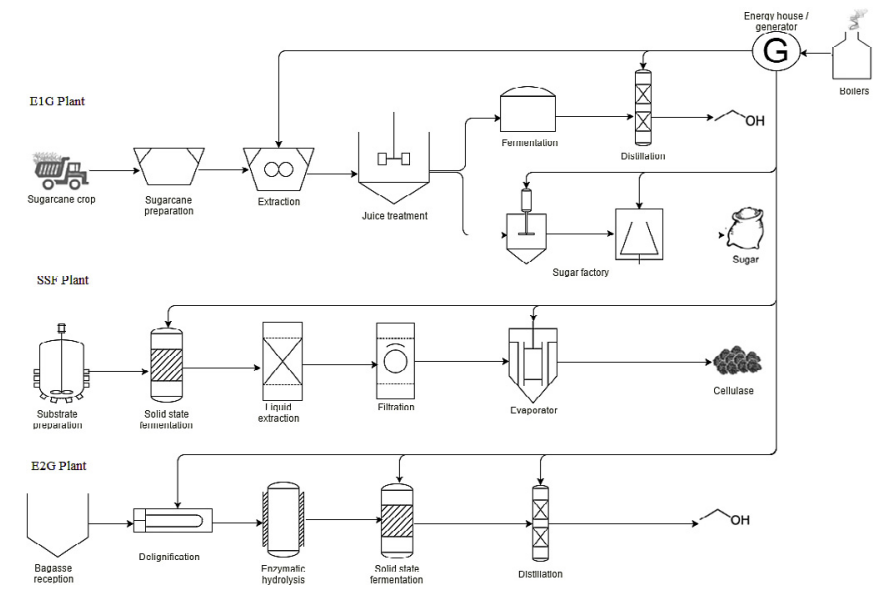

Fig. 1. Integrative flowchart among the first generation, second generation and solidstate fermentation processes. 
enzyme extract should be transported from the EPP to the E2G plants. Besides, it is expected that the enzyme produced will be continually consumed by the E2G plant and no storage would be required; if the EPP is built away from the E2G, such storage should be forecasted.

However, when analyzing the economic scenario of a possible integration, one must consider that, nowadays, E1G plants sell the surplus of electrical energy directly to the consumers, through the free contracting market (to the electricity trade companies, generators and free consumers), or through electricity purchase auctions, regulated by the Power Commercialization Chamber (to the distribution companies), here called the spot market. In addition, surplus of sugarcane bagasse is also sold to power plants installed in industries other than E1G by trade prices. Nevertheless, the study here presented will not discuss in deep these variables, representing an optimistic scenario.

\section{Methods}

\subsection{SSF process in laboratory}

The industrial SSF process will be based on the results in bench scale experiments of Zanelato et al. [9] and Casciatori [10]. These authors used sugarcane bagasse and wheat bran as substrate to cultivate the fungus Myceliophtora thermophila I-1D3b in packedbed bioreactors. Table 2 presents the main information of the fermentation process.

According to Zanelato et al. [9] and Casciatori [10], no contamination was observed during the experiments, even if no specific microbial filter was used to purify the air flowing throughout the bioreactors. Such characteristic might be attributed to the thermophilic character of the microorganism and to the low water activity of SSF processes. For industrial purposes, low contamination reduces drastically fixed and variable costs of the SSF facility.

The genome of the thermophilic fungus $M$. thermophila was sequenced Berka and co-workers [25] due to its importance as a cellulase producer and the variety I-1D3b has proved to synthesize a pool fibrolytic enzymes (endoglucanases, beta-glucosidases, xylanases and others) [10]. Enzymes from thermophilic strains are often thermostable [26]; e.g., the optimal activities endoglucanase and xylanase from $M$. thermophila I-1D3b take place at $75^{\circ} \mathrm{C}$ [27], while the same enzymes from Trichoderma reesei are more active at $60^{\circ} \mathrm{C}$ [28]. This is an important feature for the enzymatic route of the E2G production, since the most common pretreatment techniques to breakdown the fiber structure (hydrothermal and steam explosion) are carried out at high temperatures. Therefore, the pretreated bagasse must be cooled down to the optimal

\section{Table 2}

Operational condition in bench scale SSF packed bed bioreactors (extracted from Zanelato et al., 2011, and Casciatori, 2015).

\begin{tabular}{|c|c|}
\hline Parameter & Value \\
\hline Proportion sugar cane bagasse to wheat bran (weight) & $7: 3$ \\
\hline Moisture content (\%, w.b.) & 75 \\
\hline Temperature $\left({ }^{\circ} \mathrm{C}\right)$ & 45 \\
\hline Cultivation time $(\mathrm{h})$ & 96 \\
\hline Packed bed bulk density $\left(\mathrm{kg} \cdot \mathrm{m}^{-3}\right)$ & 330 \\
\hline Aeration rate $\left({\left.\mathrm{L} . \mathrm{h}^{-1} \cdot \mathrm{kg}^{-1}\right)}\right.$ & 267 \\
\hline Bioreactor diameter $(\mathrm{cm})$ & 7.62 and 20 \\
\hline Bioreactor Length $(\mathrm{cm})$ & From 40 to 200 \\
\hline Endoglucanase activity (U/g.d.s ${ }^{\mathrm{a}}$ ) & up to 800 \\
\hline FPU ${ }^{b}$ activity (U/g.d.s) & up to 12 \\
\hline
\end{tabular}

temperature for the enzyme activity, which is higher for the thermophilic strains, reducing refrigeration costs. Besides, the viscosity of the fluids and the heat and mass transfer rates are favored by the high temperature during the enzymatic hydrolysis.

The choice for the substrate, wheat bran and sugarcane bagasse, is based on the previous experience of the group and on the availability of these materials. Sugarcane bagasse is already available in the sugar mills and there is no costs to transport this material to the EPP. Wheat bran is used as an inducer of initial growth in this process, because it has an adequate balance of nitrogen, carbon and phosphorous components, along with other micronutrients $[13,29]$. Additionally, wheat bran is largely available in Brazil. The replacement of wheat bran for another substrate for $M$. thermophila I-1D3b growth would require specific tests in this is beyond the scope of this work.

\subsection{SSF industrial process}

All moisture contents in this work refer to the wet basis.

It was assumed an average Brazilian sucro-energetic industry for this case study. This unit processes 1.6 million tons of cane per season and produces $67,000 \mathrm{~m}^{3}$ of ethanol and 142,000 tons of sugar. Therefore, it produces 420,000 tons of bagasse at $50 \%$ moisture content and 304,000 tons of straw is left in the field at 15\% moisture content. About $5 \%$ of the total bagasse (21,000 tons) is kept as an energetic reserve for the process start up at the beginning of the following season and 71\% (300,000 tons) is burned in the power plant. A second stream of bagasse will be used in the E2G plant and a third in the SSF enzyme process. The average consumption of steam in the E1G plant is $420 \mathrm{~kg}$ of steam/ton of processed cane, considering an efficiency of 2.28 ton of steam/ton of bagasse of the boilers. In this calculation, it was considered a non-stop E1G process, a situation that seldom takes place in a real scenario due to technical stops, while the boilers runs continually, requiring a surplus of nearly $5 \%$ of bagasse. Hence, about $20 \%$ of the total bagasse would be available for the E2G process and for the SSF enzyme production, corresponding to 80,000 tons.

\subsection{Mass balance}

The cultivation time suggested by Zanelato et al. [9] and Casciatori [10] for the SSF was $96 \mathrm{~h}$; therefore, it will be here assumed an extra day to load and unload the bioreactors, including sterilization procedures and extraction of the enzymes from the solid fermented medium. The microorganism should be previously cultivated in inoculation tanks, where the spore suspension are prepared, which is enriched by some nutrients. In the packed bed bioreactor, the substrate, previously sterilized, is loaded, along with the spore suspension.

Three scenarios of availability of sugarcane bagasse for the SSF process were evaluated in this case study: 2800, 5600 and 8400 tons of wet bagasse, corresponding to 4,000, 8000 and 12,000 tons of wet bagasse + wheat bran. Therefore, from 70,000 to 78,000 of bagasse would be sent to the E2G unit to be treated before being hydrolyzed by the produced enzymes. These scenarios will be further identified in this text as SIM1, SIM 2 and SIM 3, respectively.

The mass balance is structured from the central step of the SSF process, the bioreaction. According to the literature [30,31], the limit volume of a SSF bioreactor seems to be $50 \mathrm{~m}^{3}$, even though little experimental evidence has been produced by the literature to support such information, because systematic studies on SSF scaleup are scarce. Lima [32] performed a sensitivity analysis considering the reactor capacity $\left(5,10,25\right.$ and $50 \mathrm{~m}^{3}$ ) and found that the analyzed factors (production costs, investment, reactor costs and operational costs) asymptotically tend to a minimum value with the 
increase of the reactor volume, and the results were not significantly different for the capacities $25 \mathrm{~m}^{3}$ and $50 \mathrm{~m}^{3}$. Therefore, the volume of $25 \mathrm{~m}^{3}$ was chosen as a reference for the present case to provide some flexibility to the bioreactor design.

\subsection{Equipment capacities and costs}

It must be highlighted that this case study uses 2014 as the reference year.

The equipment capacities required for the SSF process were estimated based on the substrate load, following the scenarios SIM 1, SIM 2 and SIM3 previously mentioned. The cost of each equipment was estimated using the software Cost Estimator developed by the Colorado University, USA [33], which provides values concerning to 2002. In order to update the values to 2014, it was used the Chemical Engineering Plant Cost Index ( $\left.\mathrm{CE}_{\text {index }}\right)$, whose values for

Table 3

SSF process equipment and costs.

\begin{tabular}{|c|c|c|c|}
\hline & Equipment & Material & Cost \\
\hline 1 & $\begin{array}{l}\text { Storage tank of sugarcane } \\
\text { bagasse and wheat bran }\end{array}$ & Carbon steel & $\mathrm{CE}_{\text {index }}$ \\
\hline 2 & $\begin{array}{l}\text { Storage tank of enzymatic } \\
\text { extract }\end{array}$ & Carbon steel & $\mathrm{CE}_{\text {index }}$ \\
\hline 3 & Air compressor & - & $\mathrm{CE}_{\text {index }}$ \\
\hline 4 & Mixer & Carbon steel & $\mathrm{CE}_{\text {index }}$ \\
\hline 5 & Inoculation tank & SS $316^{a}$ & $\mathrm{CE}_{\text {index }}$ \\
\hline 6 & Packed bed bioreactor & SS 316 & $\mathrm{CE}_{\text {index }}$ \\
\hline 7 & $\begin{array}{l}\text { Air moisture conditioning } \\
\text { system }\end{array}$ & - & $\mathrm{CE}_{\text {index }}$ \\
\hline 8 & $\begin{array}{l}\text { Heating system } \\
\text { (air and bioreactor) }\end{array}$ & - & $\mathrm{CE}_{\text {index }}$ \\
\hline 9 & Centrifuge & - & $\mathrm{CE}_{\text {index }}$ \\
\hline 10 & Ultrafilter & - & $\mathrm{CE}_{\text {index }}$ \\
\hline 11 & Clean in Place system & - & $8.00 \mathrm{US} \$ / \mathrm{m}$ \\
\hline 12 & Belt conveyor $16^{\prime \prime}$ & - & $1563 \mathrm{US} \$ / \mathrm{m}$ \\
\hline 13 & Process automation ${ }^{c}$ & - & $10 \%^{\mathrm{b}}$ \\
\hline 14 & $\begin{array}{l}\text { Tube fittings, connections } \\
\text { and civil builders }{ }^{c}\end{array}$ & - & $10 \%^{\mathrm{b}}$ \\
\hline 15 & Civil construction works & - & $5 \%$ \\
\hline 16 & Engineering expenses ${ }^{c}$ & - & $15 \%^{b}$ \\
\hline 17 & Contingency ${ }^{c}$ & & $20 \%^{\mathrm{b}}$ \\
\hline
\end{tabular}

Notes:

a SS - stainless steel.

b Based on the total cost of all equipment.

c From Peters et al. (2002).
2002 and 2014 are 390.4 and 564.7, respectively.

Table 3 presents the costs of the main equipment of the SSF plant based on the $\mathrm{CE}_{\text {index }}$, on commercial prices found in Brazil, and on specific references. If the cost of a specific equipment is different from the one given by the $\mathrm{CE}_{\text {index }}$ lists due to its different capacity, its cost is estimated using the following equation [34]:

$C_{a}=\left[\frac{A}{B}\right]^{m} C_{b}$

where $C_{a}$ and $C_{b}$ are the costs of the equipment with capacity $A$ and $B$, respectively; $m$ is the cost-capacity index, which depends on the equipment in analysis.

When the index $m$ for a specific equipment is not available, usually the index of a similar equipment is adopted, being the most common value 0.7 [35]. For the packed bed bioreactor, no value was found in the CE index or any other reference; therefore, it was considered the packed-bed bioreactor as similar to a continually stirred-tank reactor with volumetric capacity equal to $15 \mathrm{~m}^{3}$, since the SSF bioreactor requires intermittent internal mixing to homogenize the culture medium and reduced temperature gradients [30]. The number of packed-bed bioreactors required will be based on the scenarios SIM1, SIM2 and SIM3.

\subsection{Operational costs}

\subsubsection{Feedstock}

The cost estimation of sugarcane bagasse and wheat bran were based on the Brazilian market information (e.g. Ref. [35]). Both materials are seasonal and their market value usually suffer considerable monthly variations, as can be seen in Fig. 2 for wheat bran, where the average value was US\$145/ton, the maximum US\$ $179 /$ ton and the minimum US\$107/ton. The commercial value of sugarcane bagasse is not well established and it is strongly impacted by the price of electric power in the spot market. The information here presented were informally obtained from sucroenergetic industries; therefore, a sensitivity analysis considering the substrate as variable was not included in the present since the chosen limits for the bagasse prices would be too artificial. In 2014, the bagasse value ranged from US\$ $9 /$ ton to US\$18/ton. For the operational cost analysis, it was considered the price of US\$17.8/ ton in order to maximize possible effects of the feedstock in the estimation.

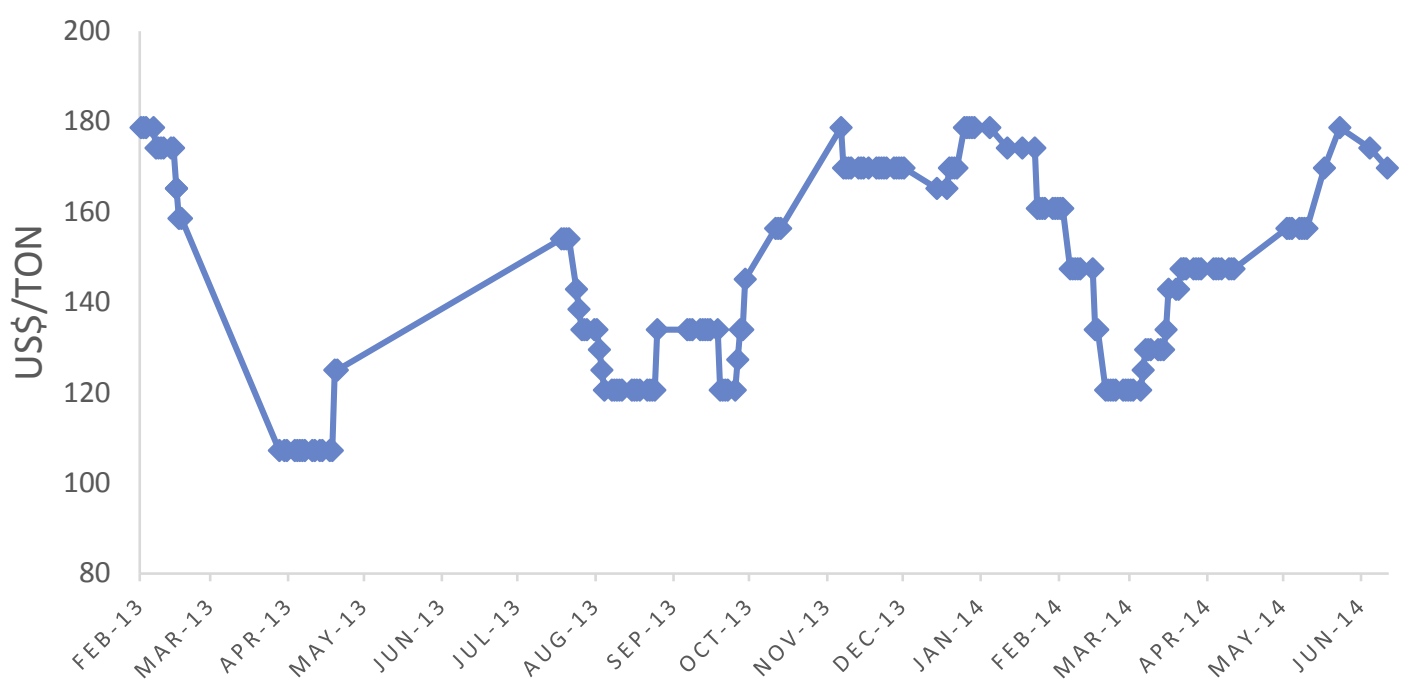

Fig. 2. Wheat bran retail price fluctuation along the past few months, from private sources. 


\subsubsection{Process utilities}

The plant capacity to produce the enzymes determines the flow of utilities required in the process, such as steam, electric energy, compressed air, and water.

\subsubsection{Labor costs}

The operational personal is partially shared by the SSF plant and the E1G plant, mainly the ones allocated in the distillery and the ones handling directly with the sugarcane bagasse. This personal usually works on shifts and often check the operational routines in control panels. The degree of education depends on the function of each employee in the SSF plant: basic education for the handlers of sugarcane bagasse and operators of mixers, filters and inoculation tanks; technical education for the operators of the SSF bioreactors; graduate personal for process control and laboratory analysis, like considered at Table 4.

The estimated labor costs necessary to complement the existent operational personal were obtained from sucro-energetic industries of similar size to the one here considered.

\subsubsection{Waste treatment}

The cultivated material in the SSF plant is rich in protein and could be destined to animal feed. Nevertheless, the toxicity of the material should be determined, since the thermophilic fungus chosen for this process is not well known in this sense. If this alternative proves to be feasible, an extra income would be added to the industry. Another possibility is to add the cultivated medium to the bagasse to be treated for the E2G production, since little of its structure is changed during the SSF process, due to the low degree of depolymerization of the sugarcane bagasse, a recalcitrant material. Other application is to burn the solid waste in the boilers after fermentation process. Hence, the costs of the solid waste treatment will not be considered in this study.

\subsection{Cash flow and economic indicators}

The fixed investments are planned for three years. In this work, to the project start-up will be assigned the Time 0 . Therefore, the total fixed investment (Capital Expenditure - CapEX) is subdivided along the three years prior to Time $0: 15 \%$ in the initial year (Time -2 ), 35\% in the second year (Time -1 ) and $50 \%$ in the third

Table 4

Labor costs partially shared by the SSF plant and Ethanol 1G.

\begin{tabular}{llll}
\hline & Sector description & $\begin{array}{l}\text { Number of } \\
\text { personal }\end{array}$ & $\begin{array}{l}\text { Total Cost } \\
\text { (US\$/month) }\end{array}$ \\
\hline EXT & Warehouse raw materials & 2 & 19.937 \\
MANUT & Maintenance & 2 & 34.022 \\
BIOTEC & Mixer/Pre-fermentation & 2 & 23.046 \\
ENZ & Bioreactor operation & 4 & 46.092 \\
LAB & Quality control/lab & 1 & 13.399 \\
LOG & Enzymatic conditioning & 2 & 26.798 \\
\hline
\end{tabular}

year (Time 0). The capital values must be yearly updated to compensate the inflation rate, and Brazilian indexes of the period 2012 to 2014 were used for such purpose.

The Microsoft Excel ${ }^{\mathbb{B}}$ spreadsheet developed by Peters et al. [33] was used in this study. This spreadsheet was developed for process economic evaluation using the following cash flow variables: annual sales; annual total product cost (TPC); annual gross profit; annual net profit; annual cash flow; construction inflation rate and annual TPC inflation rate, both fixed at $2 \%$ with income tax rate of $35 \%$ and discount rate variable from $3.5 \%$ to $11.3 \%$. Table 5 presents the main equations to calculate the listed variables. I.

Other important cash flow considerations are: zero land cost; no replacements considered; operation rate or fraction of capacity was considered during the construction plant. The plant enhances its nominal capacity after the learning curve of three years and no income tax credit taken for losses.

The economic indicators are calculated considering the three scenarios of availability of sugarcane bagasse previously defined. The chosen indicators are: return on investment (ROI), Payback, internal rate of return (IRR) and net present value (NPV).

\section{Results and discussion}

\subsection{SSF process}

The SSF process flowchart for enzyme production is presented in Fig. 3. The flowchart has been developed from the feedstock, sugarcane bagasse and wheat bran, to the final product, the enzymes. The main equipment in the process are: mixers, to homogenize the mixture sugarcane bagasse, wheat bran and nutrient solution; inoculation tank, to prepare the microbial pre-inoculum; air compressor and air heater and belt conveyor, to transport sugarcane bagasse and wheat bran. Mechanical process losses, in these calculations, were not considered. As previously mentioned, literature points out that the packed-bed reactor capacity is limited to $50 \mathrm{~m}^{3}$; therefore, it was assumed a nominal capacity of $25 \mathrm{~m}^{3}$ as a safety measure. The enzymatic extract is further manipulated using rotating vacuum filters, to separate the liquid extract from the solid fermented material; and centrifuges and ultrafilters, to clarify and concentrate the extract up to 17 fold or more [36]; and storage tanks for the concentrated extract. No special treatment is required for the concentrated extract, since it is expected that it will be used immediately in the E2G production plant. According Shyota [37] the extract can be kept at room temperature up to 30 days without decreasing significantly its cellulase activity.

The process efficiency has been considered in the economic estimators: the bioreactor is $75 \%$ filled; as previously mentioned, the cultivation time takes four days ( $96 \mathrm{~h}$ ), and two extra days are spared to prepare the bioreactor, to unload the fermented material and to extract the enzymes; $90 \%$ of cellulose is recovered to be used in the E2G process [38]. Thermal and mechanical efficiencies were not considered, since a more detailed design of the equipment would be needed.

Table 5

Equations used to determine the cash flow variables.

\begin{tabular}{ll}
\hline Variable & Equation \\
\hline Annual Sales (MUS\$) & Price $*$ Operating rate $*\left(1+\mathrm{i}_{\text {infl }}\right)^{2+\mathrm{n}}\left({ }^{2}\right)$ \\
Annual TPC (MUS\$) $\left({ }^{1}\right)$ & {$[$ Variable cost $*(1-$ Operating rate $)-$ OPEX $] *\left(1+\mathrm{i}_{\text {tpc } / \mathrm{y}}\right)^{2+\mathrm{n}}$} \\
Annual Gross Profit (MUS\$) & Start up cost + Annual sale - Annual TPC + Anuual Depreciation \\
Annual Net Profit (MUS\$) & Annual Gross Profit $*(1-$ income tax rate $)$ \\
Annual cash flow & Annual Net Profit + Annual Depreciation \\
\hline
\end{tabular}

Notes: ${ }^{1}$ - TPC: Total Product Cost; ${ }^{2}$ - Infl: inflation rate over the market price of cellulases.

$\mathrm{I}_{\mathrm{tpc} / \mathrm{y}}$ - inflation over the final cost - (annual percentage).Discount rate variable: $3.5 \%-11.3 \%$. 


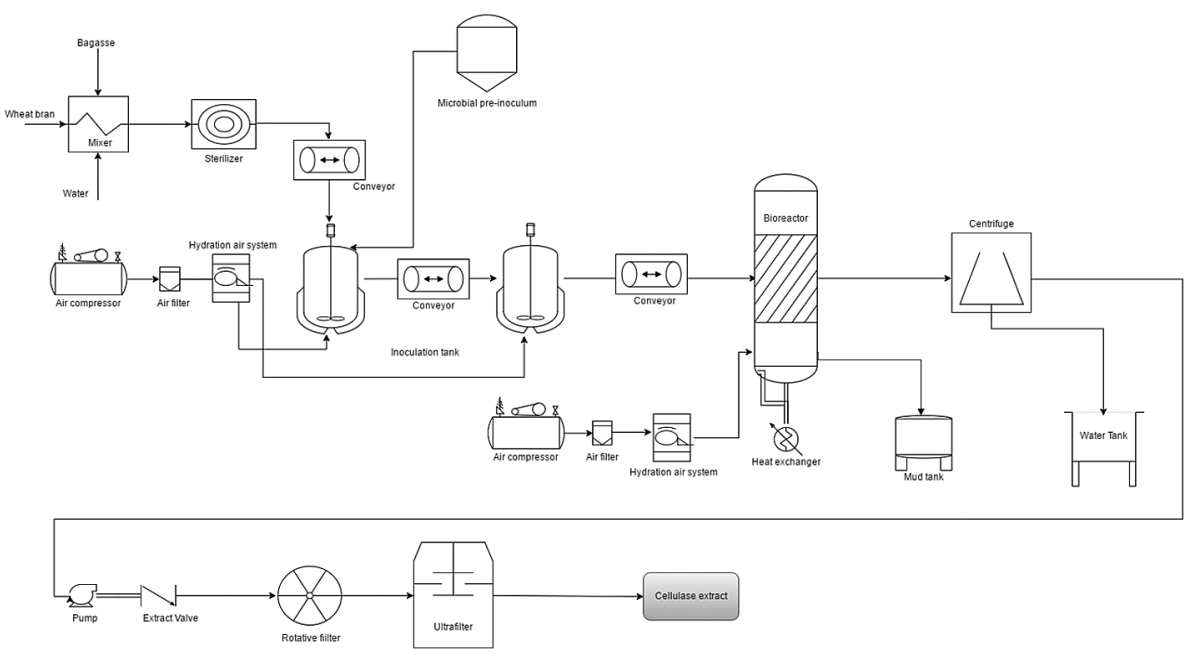

Fig. 3. SSF process flowchart for fibrolytic enzyme production.

Table 6

Dimension and quantity of equipment for the SSF enzyme production process, based on the availability of the substrate ${ }^{\mathrm{a}}$.

\begin{tabular}{|c|c|c|c|c|c|}
\hline \multirow[t]{2}{*}{ Equipment } & \multirow[t]{2}{*}{ Capacity/Power } & \multirow{2}{*}{$\begin{array}{l}\text { Cost } \\
\text { Unit (US\$) }\end{array}$} & \multicolumn{3}{|c|}{$\begin{array}{l}\text { Quantity of } \\
\text { equipment }\end{array}$} \\
\hline & & & SIM1 & SIM2 & SIM3 \\
\hline Sterilizer & $25 \mathrm{~m}^{3}$ & 181,427 & 12 & 24 & 36 \\
\hline Compressor & $75 \mathrm{~kW}$ & 88,999 & 10 & 19 & 28 \\
\hline Mixer & $50 \mathrm{~m}^{3}$ & 89,508 & 3 & 5 & 8 \\
\hline Inoculation tank & $50 \mathrm{~m}^{3}$ & 251,908 & 3 & 5 & 8 \\
\hline $\begin{array}{l}\text { Packed-bed } \\
\text { bioreactor }\end{array}$ & $25 \mathrm{~m}^{3}$ & 251,908 & 10 & 19 & 28 \\
\hline Centrifuge/filter & $10 \mathrm{ft} \times 20 \mathrm{ft}$ & 387,881 & 3 & 3 & 3 \\
\hline Ultrafilter & $58 \mathrm{~m}^{2}$ & 387,881 & 3 & 3 & 3 \\
\hline Storage tank & $90 \mathrm{~m}^{3}$ & 94,270 & 1 & 1 & 1 \\
\hline $\begin{array}{l}\text { Tank for the solid } \\
\text { residues }\end{array}$ & $100 \mathrm{~m}^{3}$ & 94,270 & 2 & 4 & 6 \\
\hline Conveyor belt & $25 \mathrm{~m}$ & $1064 / \mathrm{m}$ & - & - & - \\
\hline Helical transporter & $25 \mathrm{~m}$ & $6080 / \mathrm{m}$ & - & - & - \\
\hline
\end{tabular}

a Source: $C E_{\text {index }}$ (except belt conveyor and helical transporter).

As previously mentioned, three alternatives of availability of sugarcane bagasse and wheat bran were considered: 4,000, 8000 and 12.000 ton, corresponding to SIM1, SIM2 and SIM3. Hence, the technical project is based on the substrate availability, and Table 6 presents the dimensions of the most important equipment.

\subsection{Economic analysis}

The hydrolysis of the pre-treated bagasse depends mostly on the enzyme activity; therefore, four scenarios of enzyme activities have been considered: 6, 12, 18 and 25 FPU/g.d.s.. The broad range of enzyme activity chosen was based in the values of FPU activities found in literature of SSF having sugarcane bagasse as substrate, which ranged from 4 to $19 \mathrm{FPU} /$ g.d.s. (e.g., see Refs. [37-39]). Additionally, to assess the sensitivity of the economic indexes to the enzyme activity variation a broad range is recommended. Hence, a sensitivity analysis as a function of the enzyme activity was performed and the results of the simulations are presented in Table 7. If the average enzyme activity obtained in laboratory by Zanelato et al. [9] and Casciatori [10] is considered (12 FPU/g.d.s.), only the scenario SIM3 (12,000 ton) is acceptable, considering the reference values of Payback of 10 years recommended by experts from sugarcane mills at Sao Paulo state. Nevertheless, the IRR value was
Table 7

Economic indicators as a function of the enzyme activity and the substrate availability.

\begin{tabular}{|c|c|c|c|c|c|}
\hline $\begin{array}{l}\text { Substrate } \\
\text { availability }\end{array}$ & $\begin{array}{l}\text { Enzyme } \\
\text { activity } \\
\text { (FPU/g.d.s.) }\end{array}$ & $\begin{array}{l}\text { Enzyme cost } \\
\left.\text { (US } \$ 110^{5} \mathrm{FPU}\right)\end{array}$ & $\operatorname{IRR}(\%)^{\mathrm{a}}$ & ROI $(\%)^{b}$ & $\begin{array}{l}\text { Payback } \\
\text { (Years) }^{\mathrm{c}}\end{array}$ \\
\hline SIM1 & 6 & 10.54 & $\mathrm{NA}^{\mathrm{d}}$ & $\mathrm{NA}^{\mathrm{d}}$ & $\mathrm{NA}^{\mathrm{d}}$ \\
\hline \multirow[t]{3}{*}{4000 ton } & 12 & 5.06 & 3.5 & 3.2 & 9.5 \\
\hline & 18 & 3.51 & 13.8 & 17.6 & 4.5 \\
\hline & 25 & 2.53 & 22.2 & 35.7 & 2.7 \\
\hline SIM2 & 6 & 8.36 & $\mathrm{NA}^{\mathrm{d}}$ & - & - \\
\hline \multirow[t]{3}{*}{8000 ton } & 12 & 4.01 & 10.4 & 7.4 & 5.9 \\
\hline & 18 & 2.79 & 19.2 & 18.8 & 3.3 \\
\hline & 25 & 2.01 & 27.6 & 33.4 & 2.1 \\
\hline SIM3 & 6 & 7.81 & $\mathrm{NA}^{\mathrm{d}}$ & $\mathrm{NA}^{\mathrm{d}}$ & $\mathrm{NA}^{\mathrm{d}}$ \\
\hline \multirow[t]{3}{*}{12,000 ton } & 12 & 3.75 & 11.9 & 8.8 & 5.4 \\
\hline & 18 & 2.60 & 20.3 & 20.6 & 3.0 \\
\hline & 25 & 1.88 & 28.7 & 35.8 & 2.0 \\
\hline
\end{tabular}

Notes:

a Reference value $13 \%$.

b Reference value $30 \%$

c Reference value 5-7 years.

d NA - Not available.

under $13 \%$ and ROI under 30\%, indicating that $12 \mathrm{FPU} /$ g.d.s. is the bottom condition for the enzyme activity. From 18 FPU/g.d.s., all tested scenarios were economically satisfactory, indicating that the SSF and the E2G processes here discussed must be improved concerning the enzyme activity. Such limit should not be considered a serious impediment to the process as a whole, since alternatives of enriching the substrate and genetically modifying the microorganism could increase the enzyme activity to more acceptable values [42].

To evaluate the opportunity cost, we consider the electric generation as the best option of using the exceeding bagasse by the sucro-energetic industries. For such estimation, it was used the value of the exceeding energy sold in the spot market, US\$ 45/MWh (bid price in June/2014) [43]. Table 8 presents the amount of energy that could be generated from the sugarcane bagasse, according to the scenarios SIM1, SIM2 and SIM3, as well as the revenue originated by selling it to the distribution companies. This simulation was performed disregarding the operational costs of producing electrical energy, since the industry already produces a surplus of energy for such purpose and has the required facility.

Considering the three scenarios of availability of substrate and the enzyme activity as $12 \mathrm{FPU} /$ g.d.s., revenues presented on Table 8 
Table 8

Possible revenue to be obtained by the sucro-energetic industry when using sugarcane bagasse to produce electric energy rather than producing enzymes by SSF.

\begin{tabular}{llll}
\hline Scenario & $\begin{array}{l}\text { Sugarcane } \\
\text { bagasse (ton) }\end{array}$ & $\begin{array}{l}\text { Annual Generated } \\
\text { energy }^{\text {a }}(\mathrm{MWh})\end{array}$ & $\begin{array}{l}\text { Revenue } \\
\text { (MUS\$/crop) }\end{array}$ \\
\hline SIM1 & 2,900 & 25,135 & 1.12 \\
SIM2 & 5,700 & 50,275 & 2.25 \\
SIM3 & 8,600 & 75,410 & 3.37 \\
\hline
\end{tabular}

Note:

a Estimated energy produced from high pressure boilers (60 bar) and steam turbine with specific consumption of $4.2 \mathrm{MWh} /$ ton of steam. Among the substrates, only bagasse is burned to produce electrical energy.

show that investment on enzyme production in the SSF plant is profitable, due the increase of the revenue in four folds when compared with the revenue obtained from electric energy production. Such analysis must be cautiously considered due to the high oscillation of the electrical energy price. Dias et al. [44] showed that the E2G is not competitive with the electrical energy production considering the electricity energy at an average price of US\$ 70.5/MWh. If the E2G process could be optimized (by using the sugarcane trash, improving the hydrolysis efficiency, and reducing the costs of the enzymes), the technology would be competitive. However, if the electrical energy bid price used in the current study was used (US\$ 45/MWh), certainly the results of Dias et al. [45] would be more favorable to the E2G, as claimed by Seabra and Macedo [46], since the price of the E2G ethanol would be equal to US\$ 0.36/L if the electricity would cost US\$ 50/MWh.

The influence of the production scale is significant, as can be seen in the cashflow presented in Fig. 4. According to the literature $[46,47]$, the cashflow is forecasted up to 20 years in projects for enzyme production. The influence of the production scale on the cashflow is due to the cost of the feedstock, increasing the economic revenue with the increase of the sugarcane bagasse availability.

Cost analysis developed in the National Renewable Energy Laboratory - NREL, presented by Kazi [47], for a cellulosic ethanol plant, showed a total investment of 434 MMUS\$ spread in 20 years to produce $179.4 \mathrm{MM} \mathrm{L}$ of ethanol through on-site enzyme production route, at a cost of 0.936 US\$/liter. In his study, enzyme production cost represented 0.121 US\$/liter of ethanol during the whole plant life. It performs a significant fraction of $13 \%$ of the total operational cost, which demonstrates that enzyme cost keeps important role at the whole process cost. . Others economic studies of cellulosic ethanol plants demonstrated investments ranging from 200 to 360 MMUS\$ in 20 years, with IRR variations between 7.7 and $16.8 \%$. Economic indicators in Table 9 presents similar IRR for the on-site SSF enzyme production plant for the highest scenarios of sugarcane bagasse availability and acceptable paybacks over 5 years, considering the targets of the sucro-energetic sector.

Since no economic studies have been found in open literature on industrial enzyme production by SSF, the comparison here adopted will be with the E1G and E2G processes. Dias et al. [48] estimated an investment of 200 MMUS\$ in an E2G plant adjoined to an E1G plant of similar size as the one studied in the present work. The Brazilian Bioethanol Science and Technology Laboratory - CTBE [49] performed a deep analysis of the E2G production considering several scenarios of integration with E1G plants, integration with sugar mill plants and stand-alone E2G plants. For the integrated E1G - E2G processes, the E2G plant would cost 346 MMUS\$. According to the CTBE, the ethanol produced by the E2G process would cost US\$ $0.39 / \mathrm{L}$, considering the enzyme cost of US\$ $0.11 / \mathrm{L}$, similar to the one obtained in the current study. Seabra et al. [50] reckoned the total cost of a E2G plant at 152 MMUS\$ and the minimum price of the E2G produced at US\$ $0.32 / \mathrm{L}$, considering the purchase of enzymes in the market at US\$ 0.265/L. The authors did not include the price of the sugarcane bagasse in the study, since they considered the bagasse as a solid residue, which is a drawback, since the bagasse has a market value as it was shown in the present study. Seabra and co-workers [50] briefly discussed the possibility of on-site producing the enzymes, but the minimum cost of the ethanol (US\$ $0.37 / \mathrm{L}$ ) and the enzyme production plant cost (nearly 180 MMUS\$) were considered disadvantageous. Therefore, according to Table 8, Capital Expenditure of the SSF plant to produce enzymes for the E2G plant (38.9 MMUS\$ for the most favorable scenario - SIM 3) represents $25 \%$ or less of the investment of the E2G plant, indicating an interesting option for a biofuel industrial complex.

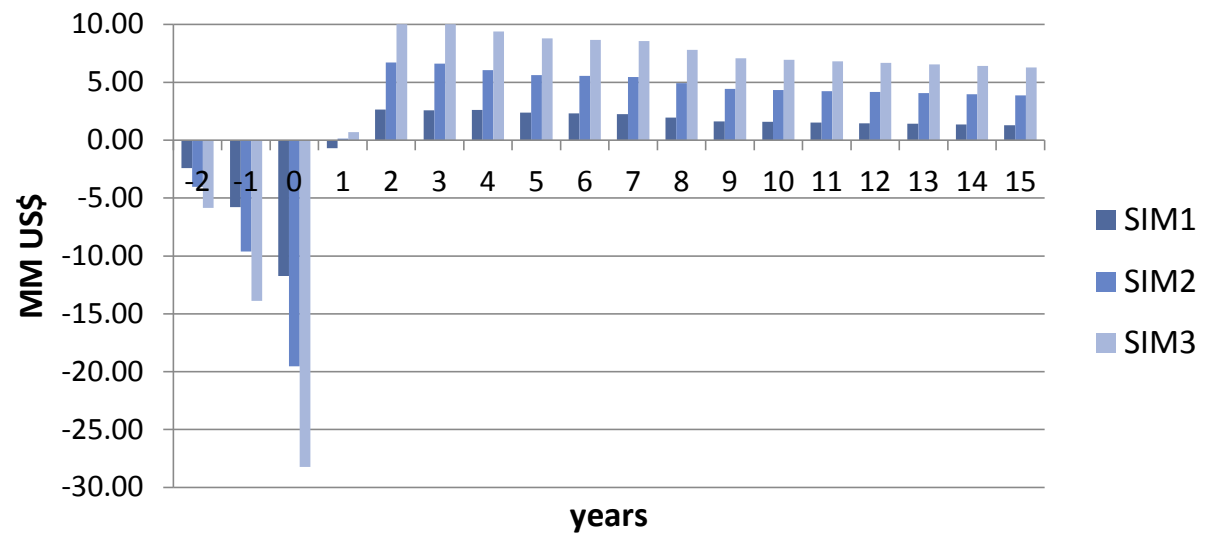

Fig. 4. 15 years cashflow calculated from the three scenarios SIM1, SIM2 and SIM3.

Table 9

Summary of the economic indexes for the SSF enzyme production process, considering the enzyme activity as $12 \mathrm{FPU} / \mathrm{g}$.d.s.

\begin{tabular}{|c|c|c|c|c|c|c|c|}
\hline & Substrate (ton) & CAPEX (MUS\$) & OPEX (MUS\$/crop) & R.O.I (\% per year) & Payback (year) & IRR (\%) & NPV (MUS\$/crop) \\
\hline SIM1 & 4,000 & 16.18 & 3.43 & 3.2 & 9.5 & 3.5 & 18.4 \\
\hline SIM2 & 8,000 & 26.93 & 5.44 & 7.4 & 5.9 & 10.4 & 53.99 \\
\hline SIM3 & 12,000 & 38.90 & 7.63 & 8.8 & 5.4 & 11.9 & 86.52 \\
\hline
\end{tabular}


The economic indicators presented in Table 7 are in the same range of the ones observed in the E2G literature. The IRR presented by Dias and co-workers [48] ranged from 12.2 to $15.9 \% /$ year, similar to the best scenario here obtained (SIM 3-12,000 tons) for enzyme activities over than 12 FPU/g.d.s.. Seabra and Macedo [45] presented a ROI of $15.9 \%$, which would be achieved only for enzyme activities over $18 \mathrm{FPU} /$ g.d.s., even though the authors alert that the electricity production is still the best option ( $\mathrm{ROI}=23.2 \%$ ).

\section{Conclusion}

The study of investment on a solid-state fermentation process to produce cellulolytic enzymes in a facility adjoined to a first generation ethanol and to a second generation ethanol production plants was done, considering sugarcane as feedstock for the E1G plant and the resulting bagasse as feedstock for the E2G and SSF production plants. Wheat bran and sugarcane bagasse were used as substrates for the enzyme production, having the thermophilic fungus Myceliophtora thermophila I-1D3b as microbial agent.

The results indicated that the best investment conditions are obtained for enzyme activity over than 12 FPU/g.d.s. (grams of dry solid substrate) on the three scenarios of substrate availability $(4000,8000$ and 12,000 tons of bagasse + bran), when the economic indicators are acceptable. For such conditions, the final cost of the enzyme produced ranged from U\$\$ $1.88 / 10^{5}$ FPU to U\$ $\$ 3.51$ / $10^{5} \mathrm{FPU}$, depending on the enzyme activity and on the feedstock load. The revenue resulting of the production of enzymes by the SSF process showed to be competitive with the revenues of the production of electric energy obtained by burning the bagasse in power plants, even though this result must be taken cautiously due the high volatility of the prices of the electricity in Brazil.

Since the amount of sugarcane bagasse used in the SSF process does not represent a risk to the current activity of the sucroenergetic industry and that the economic indicators are favorable, main aspects that should be considered in advance are the SSF optimization and the electricity cost. The SSF technical aspects that need to be improved are the enzyme activity, which must go over 12 FPU/g.d.s., and the process scale-up, from the bench to the industrial scale. The cost of electrical energy must be considered in long term, since high price fluctuations usually take place in developing countries similar to Brazil.

\section{Acknowledgment}

The authors are grateful to FAPESP for the financial support (Proc. 23453-3) and to CAPES for the scholarship.

\section{References}

[1] ANFAVEA. National Association of Vehicle Manufacturers. 2016. http://www. anfavea.com.br/tecnica.html (in Portuguese).

[2] UNICA. Brazilian Sugarcane Industry Association. Link: www.unica.com.br. Last accessed: January, 2016.

[3] N. Sarkar, S.K. Ghosh, S. Bannerjee, K. Aikat, Bioethanol production from agricultural wastes: an overview, Renew. Energy 37 (2012) 19-27.

[4] Brazil, Brazilian Agricultural Supply - CONAB. Annual Report, Brasília, 2014 (in Portuguese).

[5] A. Amore, V. Faraco, Potential of fungi as category I Consolidated bioprocessing organisms for cellulosic ethanol production, Renew. Sust. Energy Rev. 16 (2012) 3286-3301.

[6] D.G. Haki, S.K. Rakshit, Development of industrially important thermostable enzymes: a review, Biores. Technol. 89 (2003) 17-34.

[7] A.L.G. Lima, R.P. Nascimento, E.P.S. Bon, R.R.R. Coelho, Streptomyces drozdowiczii cellulase production using agro-industrial by-products and its potential use in the detergent and textile industries, Enzyme Microb. Technol. 37 (2005) $272-277$.

[8] S. Macrelli, J. Mogensen, G. Zacchi, Techno-economic evaluation of 2nd generation bioethanol production from sugarcane bagasse and leaves integrated with the sugar-based ethanol process, Biotechnol. Biofuels 5 (2012) 22.

[9] A.I. Zanelato, V.M. Shiota, E. Gomes, R. da Silva, J.C. Thoméo, Endoglucanase production with the newly isolated Myceliophtora $s p . \mathrm{i}-1 \mathrm{~d} 3 \mathrm{~b}$ in a packed bed solid state fermentor, Braz. J. Microbiol. 43 (2012) 1536-1544.

[10] F.P. Casciatori, Packed Bed Bioreactors for Solid-state Fermentation: Scale-up for Fungal Celullase Production, DSc Thesis, Paulista State University - UNESP, 2015, p. 177 (in Portuguese).

[11] G.H. Hansen, M. Lübeck, J.C. Frisvad, P.S. Lübeck, B. Andersen, Production of cellulolytic enzymes from ascomycetes: comparison of solid state and submerged fermentation, Proc. Biochem. 50 (2015) 1327-1341.

[12] F.P. Casciatori, A. Bück, J.C. Thoméo, E. Tsotsas, Two-phase and twodimensional model describing heat and water transfer during solid-state fermentation within a packed-bed bioreactor, Chem. Eng. J. 287 (2016) $103-116$.

[13] K. Brijwani, H.S. Oberoi, P.V. Vadlani, Production of a cellulolytic enzyme system in mixed-culture solid-state fermentation of soybean hulls supplemented with wheat bran, Proc. Biochem. 45 (2010) 120-128.

[14] C. Martin, M. Galbe, C. Frederik Wahlbom, B. Hahn-Hägerdal, L.J. Jönsson, Ethanol Production from enzymatic hydrolysates of sugarcane bagasse using recombinant xylose utilising S. cerevisiae, Enzyme Microb. Technol. 31 (2002) $274-282$.

[15] E.R. Stephens, I.L. Ross, Z. King, J.H. Mussgnun, O. Kruse, C. Posten, M. Borowitzka, B. Hankamer, An economic and technical evaluation of microalgal biofuels, Nat. Biotechnol. 8 (2010) 126-128.

[16] M. Novello, J. Vilasboa, W.D.H. Schneider, L. Reis, R.C. Fontana, M. Camassola, Enzymes for second generation ethanol: exploring new strategies for the use of xylose, RSC Adv. 41 (2014) 21361-21368.

[17] E. Gomes, A.P. Aguiar, C.C. Carvalho, M.R.B. Bonfá, R. Da Silva, M. Boscolo, Ligninases production by basidiomycetes strains on lignocellulosic agricultural residues and their application in the decolorization of synthetic dyes, Braz. J. Microbiol. 40 (2009) 31-39, http://dx.doi.org/10.1590/S151783822009000100005.

[18] Y.H. Ju, L.H. Huynh, N.S. Kasim, T.J. Guo, J.H. Wang, A.E. Fazary, Analysis of soluble and insoluble fractions of alkali and subcritical water treated sugarcane bagasse, Carbohydr. Polym. 83 (2011) 591-599, http://dx.doi.org/ 10.1016/j.carbpol.2010.08.022.

[19] M. Moretti, Ligno-hemicellulases Production by Solid State Fermentation and the Evaluation of Enzyme Application under Chemical Composition and Biomass Structure, Dsc. Thesis, UNESP-IBILCE, 2013 (in Portuguese/English). 128pp..

[20] R.R. Singhania, R.K. Sukumaran, A.K. Patel, C. Larroche, A. Pandey, Advancement and comparative profiles in the production technologies using solidstate and submerged fermentation for microbial cellulases, Enzyme Microb. Technol. 46 (2010) 541-549.

[21] X. Jiang, A. Geng, N. He, Q. Li, New isolate of Trichoderma viride strain for enhanced cellulolytic enzyme complex production, J. Biosc. Bioeng. 111 (2011) 121-127.

[22] M.M.S. Moretti, D.A. Bocchini-Martins, R. Da Silva, A. Rodrigues, L.D. Sette, E. Gomes, Selection of thermophilic and thermotolerant fungi for the production of cellulases and xylanases under solid-state fermentation, Braz. J. Microbiol. 43 (2012) 1062-1071.

[23] NOVOZYMES: Industrial Biotechnology. Annual Report. Link <http:// report2012.novozymes.com/Service/Download+report/The-NovozymesReport-2012.pdf>, pg.10. Retrieved january 2014.

[24] D. Klein-Marcuschamer, P.O. Popiel, B.A. Simmons, H.W. Blanch, The Challenge of enzyme cost in the production of lignocellulosic biofuels, Biotechnol. Bioeng. 109 (2012) 1083-1087.

[25] R.M. Berka, et al., Comparative genomic analysis of the thermophilic biomassdegrading fungi Myceliophthora thermophila and Thielavia terrestris, Nat. Biotechnol. 29 (2011) 922-927.

[26] R. Maheshwari, G. Bharadwaj, M.K. Bhat, Thermophilic fungi: their physiology and enzymes, Microb. Mol. Biol. R. 64 (2000) 461-488.

[27] A.I. Zanelato, Cellulolytic Enzymes Production by Solid State Fermentation in Fixed Bed Bioreactor/Alex Izuka Zanelato, Msc., São José do Rio Preto, SP Brasil: [s.n.], 2011, p. 53 (in Portuguese).118 pp..

[28] A. Durand, D. De La Broise, H. Blachere, Laboratory scale bioreactor for solic state processes, J. Biotechnol. 8 (1988) 59-66.

[29] M. Camassola, A.J.P. Dillon, Production of cellulases and hemicellulases by Penicillium echinulatum grown on pretreated sugar cane bagasse and wheat bran in solid-state fermentation, J. Appl. Microbiol. 103 (2007) 2196-2204.

[30] A. Durand, Bioreactor designs for solid state fermentation, Biochem. Eng. J. 13 (2003) 113-125.

[31] B.K. Lonsane, G. Saucedo-Castaneda, M. Raimbault, S. Roussos, G. ViniegraGonzalez, N.P. Ghildyal, M. Ramakrishna, M.M. Krishnaiah, Scale-up strategies for solid state fermentation systems, Proc. Biochem. 27 (1992) 259-273.

[32] C.A.F. Lima, Economic Evaluation of the Production Process of Cellulase through Solid-state Cultivation, MSc Dissertation, São Paulo University, 2011 (in Portuguese).

[33] M. Peters, K. Timmerhaus, R. West, Plant Design and Economics for Chemical Engineers, fifth ed., Mac Graw-Hill, 2002.

[34] W.D. Baasel, Preliminary Chemical Engineering Plant Design, second ed., Van Nostrand Reinhold, New York, 1990, p. 572.

[35] CLIC Mercado. Price Cotation. <www.clicmercado.com.br/novo/cotacoes>. Retrieved june, 2014.

[36] J.J. Virgen-Ortíz, V. Ibarra-Junquera, J.A. Osuna-Castro, P. Escalante-Minakata, N.A. Mancilla-Margalli, J.D.J. Ornelas-Paz, Method to concentrate protein solutions based on dialysis-freezing- centrifugation: enzyme applications, Anal. 
Biochem. 426 (2012) 4-12, http://dx.doi.org/10.1016/j.ab.2012.03.019.

[37] V.M. Shiota, Drying of Fungal Cellulases Using Spray-drying, Msc. São José do Rio Preto, 2014, 115 f. (in Portuguese).

[38] E. Heinzle, A.P. Biwer, C.L. Cooney, Development of Sustainable Bioprocesses: Modeling and Assessment, Wiley, 2006, pp. 3-112.

[39] R. Dueñas, R.P. Tengerdy, M. Gutierrez-Correa, Cellulase production by mixed fungi in solid-substrate fermentation of bagasse, World J. Microbiol. Biotechnol. 11 (1995) 333-337.

[42] X. Fang, S. Yano, H. Inoue, S. Sawayama, Strain improvement of Acremonium cellulolyticus for cellulase production by mutation, J. Biosc. Bioeng. 107 (2009) 256-261.

[43] CCCE. Chamber of Eletric Energy Trading. Disponible in PDF file at: www.ccee org.br/cs/idcplg? IdcService=GET_F. n=web\&RevisionSelectionMethod=latestReleased. (Accessed 27 April 2015). (in Portuguese).

[44] M.O.S. Dias, T.L. Junqueira, O. Cavalett, M.P. Cunha, C.D.F. Jesus, C.E.V. Rossell, R. Maciel Filho, A. Bonomi, Integrated versus stand-alone second generation ethanol production from sugarcane bagasse and trash, Biores. Technol. 103 (2012) 152-161.

[45] J.E.A. Seabra, I.C. Macedo, Comparative analysis for power generation and ethanol production from sugarcane residual biomass in Brazil, Energ Pol. 39 (2011) 421-428.

[46] A.M. Castro, D.F. Carvalho, D.M.G. Freire, L.R. Castilho, Economic analysis of the production of amylases and other hydrolases by Aspergillus awamori in solidstate fermentation of babassu cake, Enzyme. Res. 2010 (2010) 1-10.

[47] F.K. Kazi, J. Fortman, R. Anex, G. Kothandaraman, D. Hsu, A. Aden, A. Dutta, Techno-economic Analysis of Biochemical Scenarios for Production of Cellulosic Ethanol, National Renewable Energy Laboratory, United States of America, 2010.

[48] M.O.S. Dias, M.P. Cunha, C.D.F. Jesus, G.J.M. Rocha, J.G.C. Pradella, C.E.V. Rossell, R. Maciel Filho, A. Bonomi, Second generation ethanol in Brazil: can it compete with electricity production? Biores. Technol. 102 (2011) 8964-8971.

[49] CTBE - Bioethanol Science and Technology Laboratory, The Virtual Sugarcane Biorefinery (VSB), Technological Assessment Program (PAT). Report. 2011. Campinas, 2012, http://ctbe.cnpem.br/wp-content/uploads/2014/07/vsbreport-2011.pdf.

[50] J.E.A. Seabra, L. Tao, H.L. Chum, I.C. Macedo, A techno-economic evaluation of the effects of centralized cellulosic ethanol and co-products refinery options with sugarcane mill clustering, Biomass Bioenerg. 34 (2010) 1065-1078. 